\title{
Üniversite Öğrencilerinin Algıladıkları Anne Baba Tutumu ile Bağışlama Düzeylerinin İlişkisi
}

\author{
DOI: $10.26466 /$ opus.470406 \\ $\underline{\text { Aslı Tunca* }}^{*}$ Emine Durmuş** \\ *Doktora Öğr., İnönü Üniversitesi, Eğitim Fakültesi, Eğitim Bilimleri Böl., Malatya / Türkiye \\ E-Posta: asli hlvc@hotmail.com \\ ORCID: $\underline{0000-0001-5202-2496}$ \\ ${ }^{* *}$ Doç. Dr., İnönü Üniversitesi, Eğitim Fakültesi, Eğtim Bilimleri Bölümü, Malatya / Türkiye \\ E-Posta: emine.durmușinonu.edu.tr \\ ORCID: $\underline{0000-0002-7102-5833}$
}

\section{Öz}

Bu araştırmanın amacı üniversite öğrencilerinin algıladıkları ana-baba tutumları ile bağışlama düzeyleri arasındaki ilişkiyi incelemektir. Araştırmanın çalışma grubu İönü Üniversitesinin farklı fakültelerinde (Ĕ̆itim Fakültesi, Fen-Edebiyat Fakültesi, İletişim Fakültesi ve İktisadi ve İdari Bilimler Fakültesi) 2016-2017 bahar döneminde öğrenim görmekte olan 389 (278 kadın, 111 erkek) öğrenci oluşturmaktadır. Araştırmada, çalışmaya pratiklik ve hız kazandırması amacıyla örnekleme yöntemi olarak kolay ulaşılabilir durum örneklemesi kullanılmıştır. Kişisel bilgi formu, Ana-baba tutumları ölçeği ve Heartland affetme ölçeği; Psikolojik Danışmanlık ve Rehberlik, Sinıf Öğretmenliği, Türk Dili ve Edebiyatı, Felsefe, İktisat, Halkla İlişkiler ve Sosyoloji bölümü öğrencilerine gönüllülük esasına göre dağıtılmış ve veriler toplanmıştır. Bağışlama ve ana-baba tutumları arasındaki ilişki Spearman-Brown Sıra Farkları Korelasyon analizi ile test edilmiş, bağışlama puanlarının cinsiyete göre farklılaşıp farklılaşmadığı Mann Whitney-U testi ile analiz edilmiştir. Bulgulara göre, anne ve babasın demokratik olarak algılayan üniversite öğrencilerinin kendini ve durumu bağış̧lama eğilimleri daha yüksek ve arasında pozitif yönde anlaml ilişki bulunmuştur. Buna ilave olarak algllanan ana-baba tutumu koruyucu-istekçi ve otoriter tutum olan üniversite öğrencilerinin genel, kendini ve durumu bă̆ışlama eğilimlerinin düşük ve aralarında negatif yönde anlamlı bir ilişki saptanmıştır. Ayrıca araştırma bulgularına göre üniversite öğrencilerinin bağışlama eğilimleri (genel, kendini, başkalarını ve durumu) cinsiyet açısından anlamlı farklılık göstermemiştir. Bulgular alan yazın ışı̆̆ında tartışılmış ve öneriler sunulmuştur.

Anahtar Kelimeler: Ana-baba tutumu, bağış̧lama, üniversite öğrencileri, korelasyon, demokratik ana-baba tutumu. 


\title{
The Relation Between University Students' Perceived Parental Attitudes and Forgiveness Levels
}

\begin{abstract}
The purpose of this study is to investigate the relationship between university students' perceived parental attitudes, levels of forgiveness and whether forgiveness levels vary by gender. This descriptive study was conducted using the relational screening model. The population of the study was the university students at İnönü University. Its participants were 389 university students, 278 females and 111 males. In the study, easy-to-reach sampling was used as a sampling method in order to provide practicality and speed to the study. The data were collected using a personal information form, the Parental Attitude Scale and the Heartland Forgiveness Scale. Since the data of the study were not normally distributed, the Spearman-Brown order differentiation correlation test was used to determine the relationships between the university students' perceived parental attitudes (democratic, authoritarian and protective-demanding) and the students' forgiveness tendencies (general, forgiving themselves, forgiving others and forgiving situations). The Mann Whitney-U test was used to determine whether forgiveness scores varied by gender. Based on these findings no statistically significant relationship between parental attitudes and forgiving others was found in this study. The participants whose perceived parental attitude was democratic had higher tendencies to forgive themselves and situations. However, the participants who perceived their parents as protective-demanding or authoritarian had lower levels of general forgiveness, forgiving themselves and situations. This study found that the forgiveness tendencies of university students did not differ significantly by gender.
\end{abstract}

Keywords: Parental attitude, forgiveness, university students, correlation, democratic parental attitude. 


\section{Giriş}

Çocukluk yaşantılarının ve ebeveyn ilişkilerinin, kişinin sosyal ve duygusal yaşamında kalıcı etkilerinin olduğu, tüm ilişkilerde kendini gösterdiği bilinmektedir. Çocuğun gözlemlediği davranışlar onun ilerideki hayatında göstereceği davranışlara temel oluşturmaktadır. Her çocuk, önemsendiği insanlar tarafından sevgi, sıcaklık gibi olumlu tepkiler görme ihtiyacı duyar. Bu tür olumlu tepkilerden çocuğun mahrum kalması çeşitli uyum problemlerini beraberinde getirebilir (Rohner, 2005).

Erken çocukluk deneyimlerine ve ebeveyn ilişkilerine değinen kuramcılar ebeveyn-çocuk arasındaki ilişki biçiminin kişilik gelişiminde belirleyici unsur olarak ele alırlar. Freud'a göre çocuklukta anne ile kurulan iletişimin kalitesi ve çocuğu algılama biçiminin kişilerin yetişkinlik döneminde kuracağ 1 ilişkilere, çevresini ve kendisini algılama biçimine etkisi olacağ1 yönündedir (Schultz ve Schultz, 2002). Erikson'da (1963) benzer olarak ebeveyn ile yakınlık ilişkisinin kişinin gelecekteki sosyal ilişkiler için belirleyici olduğunu ortaya koymaktadır. İnsanlar eğer ebeveynlerinden yakınlık görmez, güven duygusu oluşmaz ise, sosyal ilişkilerden kaçma, insanları reddetme, yalnız olmayı tercih etme, yakınlıktan korkma davranışları gösterebilirler.

Ailenin davranışların edinilmesinde katkı sağlayan, övgünün ve cezanın kullanıldığı başlıca ortamlardan olduğu söylenebilir. Anne ve babanın çocuğa karşı olan tutumu ileride çevreyi algılayış biçimini temellendirir (Yavuzer, 1990). Baumrind (1966) üç farklı ebeveyn tutumu tespit etmiştir. Bunlar; otoriter tutum, koruyucu tutum ve demokratik tutumdur. Otoriter tutum, ebeveynlerin çocuklarının gelişmişlik seviyelerini, kişiliklerini ve taleplerini kayda değer bulmadıkları, çocuktan isteklerine uygun şekilde davranmalarının beklendiği tutumdur. Koruyucu tutum; ebeveynlerin çocuklarını aşırı derecede koruduğu ve denetlediği, gereğinden fazla müdahale ederek, onların yaşayarak öğrenmeleri ve kendilerine yeter hale gelmelerinin engellendiği tutumdur. Demokratik tutum ise ebeveynlerin çocuklarına koşulsuz sevgi ve saygı gösterdikleri, onlara güven verici ve tutarlı bir ortam sunan, sorumluluk almasına imkân tanıyan tutumdur. Otoriter tutumla yetişen çocuklar, sosyal ilişkilerde sorun yaşamakta, sevgi ve merak duygularından yoksun olmakta, kendini yetersiz, engellenmiş hissetmekte, kabul edilmeme ve engelle- 
melerden dolayı suçlu hissetme ve suça bulaşma eğiliminde olmaktadırlar (Gazeloğlu, 2000; Humpyres, 1998; Kehale, 2002; Kuzgun, 1991; McWhirter ve Acar, 1991). Koruyucu tutumla yetiştirilmiş bireyler dayanıksız, aşırı bağımlı, güvensiz, kararsız olabilmekte, duygu kontrolleri zayıf, sorumluluk duyguları gelişmemiş olabilmektedir (Gazeloğlu, 2000; Tuzgöl, 1998; Yavuzer, 2000; Yıld1z, 2004). Demokratik tutum, bireyin kişilik gelişimine en çok katkı sağlayan tutumdur (Baumrind, 1968). Demokratik tutumla büyümüş çocuklar üretken, başarılı, kendini kontrol edebilen, olumlu benlik algısına sahip, vicdanlı, etrafındakilere sevgi ve saygıyla yaklaşan, toplumsal ilişkilerinde uyumlu bireyler olabilmektedirler (Bilal, 1984; Dönmezer, 1999; İkizoğlu, 1993; Öztürk, 1990; Yavuzer, 2000). Anlaşılacağı üzere ebeveynlerin çocuğa gösterdiği tutum ve tavırların, ailenin yapısı ile birlikte çocuğun kişilik gelişimi üzerinde ciddi etkisinin olduğu söylenebilir. Çocuk, büyüme evresinde ebeveynleriyle kurduğu özdeşim sayesinde kişiliğinin ve karakterinin temellerini oluşturmaya başlar (Kaya, Bozaslan ve Genç, 2012).

Kişilerin anne babasıyla özdeşim kurarak oluşmaya başlayan önemli kişilik özelliği, tepkilerden (Mccullough ve Witvliet, 2002) biri bağışlamadır. Bağışlama kavramı ile yapılan bir çalışmada ebeveynlerin bağışlama düzeyleri ile çocuklarının bağışlama düzeyleri arasında benzerlik saptanmıştır (Mullet, Girard ve Bahshi, 2004). Psikodinamik yaklaşıma göre bağışlama, hayatın ilk yıllarında başlar ve kişinin diğerleri ile gerçek ya da gerçek olmayan ilişkileri içsel süreçlerinin etkileşimi sonucu oluşur. Nesne ilişkileri kuramcıları ise bağışlamayı, anneyle bebek arasında kurulan ilişki bakımından ele almış, ilk yıllara önem vermişlerdir. Anne, bebeğinin 1srarlı isteklerine karşılık vermekte ve kendisini kullanmasına izin vermektedir. Anne, bebeği tarafından kullanılmasına ve ısrarlı isteklerine kızsa bile bebeğini bağışlayıcı bir tavırla kabul etmesi, ona bağışlamayı öğretmektedir (Taysi, 2007). Piaget (1932) ise bağışlamanın çocukluğun sonuna doğru oluşmaya başladığını, karşılıklılık temeline dayandığını, 'Sana davranıldığı şekilde sen de öyle davran.' fikrine dönüştügünü savunur. Akhtar (2002), ilk ilişkilerin önemini vurgulayarak bağışlama becerisinin çocukluk dönemlerinde ebeveyn ile samimi ilişkilerden edinilen temel bağışlama becerisine dayandığı vurgulanmaktadır. İster ebeveyn ile özdeşim sonucu olsun ister anne-baba ile iletişimin kalitesi açısından düşünülsün bağışlamanın hayatın ilk yılla- 
rında oluşmaya başladığı ve öğrenildiği düşünülmektedir. Ancak alan yazın incelendiğinde bağışlama kavramının öfke duyguları (Fincham, Hall ve Beach, 2005; McCullough, Pargament ve Thoresen, 2000), kızginlık, hayal kırıklığı ve intikam (Enright, 1996), sağlıklı olma (Worthington ve Scherer, 2004), bilişsel çarpitmalar (Çivan, 2013), öznel iyi oluş (Yalçın ve Malkoç, 2015), umut, kızgınlık ve depresyon (Taysi, Curun ve Orcan, 2015) gibi farklı değişkenler ile ilişkisine bakıldığı (Alpay, 2009; Berry, Worthington, O'Connor, Parrott ve Wade, 2005; Kara, 2009; Walker ve Gorsuch, 2002) ancak aile ilişkilerindeki yerine dair sınırlı sayıda çalışma olduğu görülmektedir. Bu nedenle bu araştırmada, ebeveyn tutumları ile bağışlama ilişkisinin incelenmesi amaçlanmıştır. Bu yönü ile araştırmanın, bağışlamanın ebeveyn tutumları boyutuna dikkat çekmesi açısından orijinal bir çalışma olduğu söylenebilir.

Bağışlama, olumsuz düşünce ve davranışların yerine daha olumlu duyguların, empatinin, saygının, merhametin ve uzlaşmanın aldığı bir süreç olarak tanımlanır (Enright, Gassin ve $\mathrm{Wu}, 1992)$. Ayrıca son zamanlarda popülerlik kazanan pozitif psikolojide en çok araştırılan konuların başında gelmektedir (Aslan, Mert ve Yıldız, 2016; Battle ve Miller, 2015; Gündüz, 2014; Kaya, 2015; Sarıçam ve Biçer, 2015). Son yıllarda insanın olumlu yönlerinin de araştırılması gerektiğine vurgu yapılmaktadır. Böylelikle hakkında araştırmalar yapılan intikam, öfke gibi konuların yerine, bir karakter gücü olarak bağışlama önemli hale gelmiştir (Bono ve McCullough, 2004; Seligman, 2002). Bu bağlamda olumlu bir güç olarak değerlendirilen ve geliştirilmesi arzu edilen bağışlamanın güncel alan yazına önemli katkılar sunacağı beklenmektedir.

Zorlu yaşantılara rağmen bazı kişilerin kendi psikolojik ve fiziksel sağlıklarını da koruyarak çevreleri ile uyum içinde oldukları görülmektedir (Conner ve Davidson, 2003). Bireyin kendisi ve çevresi ile uyumlu, olumsuz koşullardan kendisini korumasını sağlayan bağışlamanın önemli bir kişilik özelliği olduğu söylenebilir (Tuck ve Anderson, 2014). Bağışlama, kişinin kendini, başkalarını ve durumu bağışlama boyutlarından oluşan bir yapıdır. Kendini bağışlama, yaptı̆̆ 1 hatadan dolayı sonra kişinin kendine öfke yerine merhamet, cömertlik ve sevginin almasıdır (Enright, 1996). Başkalarını bağışlama, kendine zarar veren kişiye yönelik olumsuz duygulardan vazgeçebilmesidir (Hall ve Fincham, 2005; Mauger, Perry, Freeman, ve Grove, 1992). Durumu bağışlama ise bireyin 
yaşanılan durum ile ilgili olumsuz duygulardan vazgeçebilmesidir (Thompson vd., 2005). Kısaca bağışlama; bireyin kendisine ve etrafına zararı olan negatif hislerinden istekli biçimde vazgeçmesi, bu hislerin kaybolması hatta olumluya dönüşmesidir (Enright, 1996; McCullough vd., 2000; Rye ve Pargament, 2002).

Bağışlamanın kişiye olan olumlu etkileri konusunda oldukça geniş çaplı araştırmalar mevcuttur (Hall ve Fincham, 2005; Karremans, Van Lange, Ouwerkerk ve Kluwer, 2003; Toussaint, Worthington ve Williams, 2015). Bağışlamanın, bağışlayana fiziksel ve ruhsal açıdan pek çok faydası bulunmaktadır (Exline ve Baumeister, 2000). Bağışlama, kişiye psikolojik ve manevi olgunluk kazandırmakta, bugünkü yaşam becerilerini geliştirmelerine katkı sağlamakta (Hope, 1987; McCullough ve Worthington, 1994), çiftlerin ilişki doyumunu arttırmakta (McCullough vd., 1998), kendini olduğu gibi kabul etmesine yardımcı olmakta (Aschleman, 1996) ve fiziksel sağlığı olumlu yönde etkilemektedir (Huang ve Enright, 2000). Bağışlamanın hem fiziksel hem de psikolojik olarak insanların üzerinde etkili olması bu kavramın önemli bir psikolojik güç kaynağı olduğunu göstermektedir. Bu yüzden psikolojide ve ilgili alanlarda bu kavramın daha çok araştırılması, Türk toplumundaki hangi etmenlerle ilişkili olduğunun anlaşılması gerektiği düşünülmektedir. Bu açıdan çalışmanın, bağışlama kavramının ana-baba tutumları ile ilişkisinin incelendiği gerekli bir araştırma olduğu söylenebilir.

$\mathrm{Bu}$ çalışmada üniversite öğrencilerinin bağışlama düzeyleri cinsiyet açısından karşılaştırılmış ve öğrencilerin algıladıkları ana-baba tutumları (demokratik, koruyucu-istekçi ve demokratik) ile bağışlama düzeyleri (genel, kendini, başkalarını, durumu) arasındaki ilişki incelenmiştir.

\section{Yöntem}

\section{Araştırma Modeli}

Araştırma, üniversite öğrencilerinin algıladıkları ana-baba tutumu ile bağışlama eğilimi arasındaki ilişkiyi inceleyen ilişkisel tarama türünde betimsel bir çalışmadır. Bu tür modellerde iki ve daha fazla değişken arasındaki değişimin varlığ 1 ve/veya derecesinin belirlenmesi amaçlanır (Karasar, 2011). 


\section{Evren ve Örneklem}

Çalışmanın hedef evrenini, İnönü Üniversitesi 2016-2017 yılı bahar döneminde öğrenime devam etmekte olan üniversite öğrencileri oluşturmaktadır. Araştırmanın çalışma evreni ise İnönü Üniversitesi Eğitim Fakültesi, Fen- Edebiyat Fakültesi, İletişim Fakültesi ve İktisadi ve İdari Bilimler Fakültesinde öğrenimine devam eden öğrencilerdir. Araştırmada, çalışmaya pratiklik ve hız kazandırması amacıyla örnekleme yöntemi olarak kolay ulaşılabilir durum örneklemesi kullanılmıştır. Araştırmaya, Eğitim Fakültesinden 224 (\%57,6), Fen-Edebiyat Fakültesinden 87 $(\% 22,4)$, İletişim Fakültesinden $33(\% 8,5)$ ve İktisadi ve İdari Bilimler Fakültesinden ise 45 (\%11,6), bunların 278'i kadın, 111'i erkek olmak üzere toplamda 389 öğrenci katılmıştır. Araştırmaya katılanların yaş aralığı 18-29 arasında değişmektedir $(x=20,64)$. Katılımcların 133'ü $(\% 34,2)$ birinci sınıf, 115'i $(\% 29,6)$ ikinci sınıf 85'i $(\% 21,9)$ üçüncü sınıf ve 56 '1 $(\% 14,4)$ dördüncü sinıf öğrencilerinden oluşmaktadır.

\section{Veri Toplama Araçları}

\section{Kişisel Bilgi Formu}

Araştırmacılar tarafından örneklemdeki öğrencilerin cinsiyet, yaş, sınıf, bölüm, anne-baba eğitim düzeyi, ekonomik düzey, ebeveynlerinin evlilik durumu ve hayatta olup olmamama durumlarının belirlenmesi amacı ile hazırlanan formdur.

Ana-Baba Tutumları Ölçeği: Ana-Baba Tutumları Ölçeği Kuzgun ve Eldeleklioğlu (2005) tarafından geliştirilmiş. Toplamda 40 madde ve üç alt ölçekten oluşmaktadır. Beşli likert tipinde hazırlanmıştır. Ölçekte, demokratik tutumu ölçen 15, otoriter tutumu ölçen 10, koruyucu-istekçi tutumu ölçen 15 madde bulunmaktadır. Ölçeğin faktöre analizleri 19921993 yıllarında Gazi Üniversitesi İdari Bilimler Fakültesi'nin 100 öğrencisinin katılımıyla yapılmıştır (Öner, 2012). Ana-Baba tutum ölçeğinin Cronbach alfa katsayıları demokratik tutum için .90, koruyucu-istekçi tutum için .82, otoriter tutum için 0.79 olarak tespit edilmiştir. Kararlılık 
katsayıları ise demokratik tutumun .92, koruyucu-istekçi tutumun .75, otoriter tutumun .79 olarak bulunmuştur (Eldeleklioğlu, 1999).

Heartland Affetme Ölçeği (Heartland Forgiveness Scale): Heartland Affetme Ölçeği Thompson vd. (2005) tarafından üniversite öğrencilerinin bağışlama düzeylerini ölçmek amacıyla geliştirilen, Bugay ve Demir (2010) tarafından Türk kültürüne uyarlama çalışması yapılan bir ölçektir. Ölçek, her bir alt boyut (kendini, başkalarını, durumu bağışlama) için 6 madde toplamda da 18 maddeden oluşmaktadır. Ölçeğin Türkçe formu yedili likert tipi puanlamalıdır. Tüm alt boyutlara ilişkin puanlar toplandığında genel bağışlama puanına ulaşılmaktadır. Ölçeğin kendini bağışlama alt ölçeğine ilişkin iç tutarlılık katsayısı .75, kararlılık katsayısı .83; başkalarını bağışlama alt ölçeğine ilişkin iç tutarlılık katsayısı .78, kararlılık katsayısı .72; durumu bağışlama alt ölçeğine ilişkin iç tutarlılık katsay1sı .79, kararlılık katsayısı .73 ve genel bağışlama puanı için iç tutarlılık kaysayısı .86, kararlılık katsayısı .77 bulunmuştur. Ölçeğin geçerliliği açımlayıcı ve doğrulayıc faktör analizi ile incelenmiştir ve ölçeğin üç faktörlü yapıya sahip olduğu saptanmıştır. Ayrıca uyum değerleri yeterli düzeyde bulunmuştur. Buna ilave olarak ölçüt geçerliği için kullanılan ölçeklerle arasında anlamlı saptanmıştır (Thompson vd., 2005). Ölçeğin Türkçe formunun geçerlik çalışmaları 376 üniversite öğrencisiyle yapılmış, doğrulayıc faktör analizi yapılmış, uyum değerleri yeterli düzeyde bulunmuştur. Ölçeğin ölçüt geçerliğini değerlendirmek için ise Yaşam Doyumu Ölçeği ve Ruminatif Tepki Ölçeği kullanılmış ve ilişki anlamlı bulunmuştur. Güvenilirlik çalışmaları için ise Cronbach alfa değerlerine bakılmış; genel bağışlama puanı için .81, kendini bağışlama için .64, başkasını bağışlama için .79 ve durumu bağışlama için .76 olarak hesaplanmıştır (Bugay ve Demir, 2010). Bu sonuçlara göre ölçeğin güvenilirlik ve geçerlilik ölçütlerini karşıladığı söylenebilir.

\section{Verilerin Toplanması}

Veriler, 2016-2017 akademik yılında Eğitim, Fen-Edebiyat, İktisadi ve İdari Bilimler ve İletişim Fakültelerinden kolay ulaşılabilir durum örnekleme yöntemi ile seçilen Psikolojik Danışmanlık ve Rehberlik, Sınıf Öğretmenliği, Türk Dili ve Edebiyatı, Felsefe, İktisat, Halkla İlişkiler, Sosyo- 
loji bölüm öğrencilerine kişisel bilgi formu ve ölçeklerin uygulanması ile elde edilmiştir. Kişisel bilgi formu ve ölçme araçları öğrencilere sınıf ortamında, araştırma hakkında bilgi verildikten sonra uygulanmıştır. Formlar araştırmaya katılım konusunda gönüllü olan öğrencilere dağ1tılmıştır. Veriler ortalama 20-25 dakika toplanmıştır. Araştırmada toplamda 403 form uygulanmış, eksik ve hatalı doldurmalardan kaynaklı 14 form elenmiş geriye kalan 389 form ile analiz gerçekleşmiştir.

\section{Verilerin Analizi}

Araştırmanın amacı çerçevesinde, üniversite öğrencilerinin algıladıkları ana-baba tutumları ile öğrencilerin bağışlama eğilimleri arasında ilişkiyi belirlemek için veriler normallik ölçütünü karşılamadığından SpearmanBrown Sıra Farkları Korelasyon analizi yapılmıştır. Cinsiyete göre öğrencilerin bağışlama düzeyleri arasında farklılık olup olmadığı Mann Whitney-U testi ile analiz edilmiştir. Anlamlılıklar en düşük .05 düzeyinde sınanmıştır. İstatistiki analizler SPSS 22.00 programı ile gerçekleştirilmiştir.

\section{Bulgular}

Araştırmaya katılan üniversite öğrencilerinin; cinsiyet, fakülte, yaş, sınıf düzeyi, anne ve baba eğitim düzeyi, ebeveynlerinin sağ olup olmama durumu, ebeveynlerin evlilik durumu ve ailenin gelir düzeyine göre dağılımı Tablo 1'de sunulmuştur.

Tablo 1'e göre araştırmada, katılımcıların büyük çoğunluğunun kadın $(278, \% 71,5)$ olduğu fakülteler arasından en çok Eğitim Fakültesinden öğrenci $(224, \% 57,6)$ bulunduğu bunlardan büyük çoğunluğunun 18-21 yaş aralığında $(289, \% 73,5)$ ve yoğunlukla birinci sinıf öğrencilerinden oluştuğu $(133, \% 34,2)$ görülmektedir. Ayrıca annesi ve babası okur-yazar ve ilkokul mezunu olan katılımcı sayının $(247, \% 63,5 ; 163, \% 41,9)$ daha fazla olduğu saptanmıştır. Katılımcıların büyük çoğunluğunun anne babasının evli $(378, \% 97,2)$ ve her ikisinin de hayatta $(364, \% 93,6)$ oldukları görülmektedir. 
Tablo 1.Katılımcılara ait demografik bilgiler

\begin{tabular}{|c|c|c|c|}
\hline & & $\mathbf{N}$ & $\%$ \\
\hline \multirow[t]{2}{*}{ Cinsiyet } & Kadın & 278 & 71,5 \\
\hline & Erkek & 111 & 28,5 \\
\hline \multirow[t]{4}{*}{ Fakülte } & Eğitim & 224 & 57,6 \\
\hline & Fen-Edebiyat & 87 & 22,4 \\
\hline & İktisadi ve İdari Bilimler & 45 & 11,6 \\
\hline & İletişim & 33 & 8,5 \\
\hline \multirow[t]{3}{*}{ Yaş } & $18-21$ & 289 & 73,5 \\
\hline & $22-25$ & 96 & 24,6 \\
\hline & $26-29$ & 7 & 1,8 \\
\hline \multirow[t]{4}{*}{ Sınıf Düzeyi } & Birinci & 133 & 34,2 \\
\hline & İkinci & 115 & 29,6 \\
\hline & Üçüncü & 85 & 21,9 \\
\hline & Dördüncü & 56 & 14,4 \\
\hline \multirow[t]{4}{*}{ Anne Eğitim Düzeyi } & Okur-yazar/İlkokul & 247 & 63,5 \\
\hline & Ortaokul & 69 & 17,7 \\
\hline & Lise & 56 & 14,4 \\
\hline & Üniversite & 17 & 4,4 \\
\hline \multirow[t]{5}{*}{ Babanın Eğitim Düzeyi } & Okur-yazar/İlkokul & 163 & 41,9 \\
\hline & Ortaokul & 68 & 17,5 \\
\hline & Lise & 101 & 26,0 \\
\hline & Üniversite & 53 & 13,6 \\
\hline & Lisansüstü & 4 & 1,0 \\
\hline \multirow{3}{*}{$\begin{array}{l}\text { Ebeveynlerin Sağ Olup Ol- } \\
\text { mama Durumu }\end{array}$} & Her ikisi de hayatta & 364 & 93,6 \\
\hline & Anne sağ baba ölü & 19 & 4,9 \\
\hline & Baba sağ anne ölü & 6 & 1,5 \\
\hline \multirow[t]{3}{*}{ Ebeveynlerin Evlilik Durumu } & Evliler & 378 & 97,2 \\
\hline & Boşandilar & 8 & 2,1 \\
\hline & Boşanmadılar ama ayrı yaşıyorlar & 3 & , 8 \\
\hline \multirow[t]{5}{*}{ Ailenin Ekonomik Düzeyi } & 600 TL ve alt1 & 17 & 4,4 \\
\hline & $600-1000 \mathrm{TL}$ & 58 & 14,9 \\
\hline & $1000-2500$ & 196 & 50,4 \\
\hline & 25000-5000TL & 103 & 26,5 \\
\hline & 5000 ve üstü & 15 & 3,9 \\
\hline
\end{tabular}

Ailenin ekonomik düzeyi açısından katılımcıların en çok 1000-2500 TL gelir düzeyine sahip $(196, \% 50,4)$ olduğu söylenebilir. Araştırmada 
değişkenlerin cinsiyete göre farklılaşıp farklılaşmadığı Mann Whitney U testi ile analiz edilmiştir, bulgular Tablo 2' de sunulmuştur.

Tablo 2. Üniversite öğrencilerinin bă̆ışlama düzeylerinin Mann Whitney U Testi Sonuçları

\begin{tabular}{lllllll}
\hline Puan & Grup & $\mathbf{N}$ & $\overline{\mathbf{x}}_{\text {sıra }}$ & $\begin{array}{l}\text { Sıra } \\
\text { toplamı }\end{array}$ & U & p \\
\hline Genel Bağışlama & K1z & 278 & 189,68 & 52730,00 & 13949,000 &, 139 \\
& Erkek & 111 & 208,33 & 23125,00 & & \\
& Toplam & 298 & & & & \\
\hline Kendini Bağışlama & K1z & 278 & 190,16 & 52863,50 & 14082,500 &, 178 \\
& Erkek & 111 & 207,13 & 22991,50 & & \\
& Toplam & 298 & & & & \\
\hline Başkalarını Bağışlama & Kiz & 278 & 195,96 & 54478,00 & 15161,000 &, 789 \\
& Erkek & 111 & 192,59 & 21377,00 & & \\
& Toplam & 298 & & & & \\
\hline Durumu Bağışlama & K1z & 278 & 189,35 & 52640,50 & 13859,500 &, 116 \\
& Erkek & 111 & 209,14 & 23214,50 & & \\
& Toplam & 298 & & & & \\
\hline
\end{tabular}

Tablo 2'ye göre Mann Whitney U testi sonucunda bağışlama puanları kadın ve erkek açısından anlamlı farklılık göstermemiştir $(p>, 05)$. Üniversite öğrencilerinin algıladıkları ana-baba tutumu ile bağışlama eğilimi arasındaki ilişkiyi belirlemek için ise Spearman-Brown Sıra Farkları Korelasyon analizi yapılmıştır. Analize ilişkin bulgular Tablo 3'de sunulmuştur.

Tablo 3.Üniversite öğrencilerinin algıladıkları ana-baba tutumu ile bağışlama düzeyleri arasındaki ilişki ve puanlara ilişkin ortalama ve standart sapma değerleri

\begin{tabular}{|c|c|c|c|c|c|c|c|}
\hline & 1 & 2 & 3 & 4 & 5 & 6 & 7 \\
\hline 1.Demokratik Tutum & - & & & & & & \\
\hline $\begin{array}{l}\text { 2.Koruyucu-İstekçi } \\
\text { Tutum }\end{array}$ &,- 098 & - & & & & & \\
\hline 3.Otoriter Tutum &,$-570^{* *}$ &, $502^{* *}$ & - & & & & \\
\hline 4.Genel Bağışlama & ,080 &,$- 172^{* *}$ &,$- 162^{* *}$ & - & & & \\
\hline 5.Kendini Bağışlama & ,196 &,$- 174^{* *}$ &,$- 170^{* *}$ & ,591** & - & & \\
\hline $\begin{array}{l}\text { 6.Başkalarını Bağış- } \\
\text { lama }\end{array}$ &,- 066 &,- 099 &,- 093 &, $695^{* *}$ & , 051 & - & \\
\hline 7.Durumu Bağışlama &, $122^{*}$ &,$- 143^{* *}$ &,$- 157^{* *}$ &, $770^{* *}$ & $350^{* *}$ &, $351^{* *}$ & - \\
\hline$x$ & 56,02 & 35,50 & 20,63 & 80,74 & 27,90 & 25,49 & 27,35 \\
\hline ss & 11,389 & 9,772 & 7,348 & 13,263 & 5,379 & 7,375 & 5,987 \\
\hline
\end{tabular}

$\mathrm{N}=389,{ }^{*} \mathrm{p}<.05,{ }^{* *} \mathrm{p}<.01$ 
Tablo 3'de görüldüğü üzere algıladıkları ana-baba tutumu demokratik olan üniversite öğrencilerinin kendini bağışlama $(r=.196, p<.01)$ ve durumu bağışlama ( $r=.122$, p<.05) eğiliminin daha yüksek olduğu görülmektedir ve aralarında pozitif yönde anlamlı bir ilişki bulunmaktadır. Ana-baba tutumunu koruyucu-istekçi olarak algılayan öğrencilerin genel bağışlama $(\mathrm{r}=-.172, \mathrm{p}<.01)$, kendini bağışlama $(\mathrm{r}=-.174, \mathrm{p}<.01)$ ve durumu bağışlama $(\mathrm{r}=-.143, \mathrm{p}<.01)$ düzeyinin düşük olduğu görülmektedir ve aralarında negatif yönde anlamlı ilişki bulunmaktadır. Algıladıkları anababa tutumu otoriter olan öğrencilerin ise genel bağişlama ( $\mathrm{r}=-.162$, $\mathrm{p}<.01)$, kendini bağışlama( $\mathrm{r}=-.170, \mathrm{p}<.01)$ ve durumu bağışlama $(\mathrm{r}=-.157$, $\mathrm{p}<.01)$ eğiliminin düşük olduğu görülmektedir ve aralarında negatif yönde anlamlı ilişki bulunmaktadır. Algılanan ana-baba tutumları ile başkalarını bağışlama eğilimi açısından anlamlı bir ilişki bulunmamıştır.

\section{Tartışma, Sonuç ve Öneriler}

Araştırma bulgularına göre üniversite öğrencilerinin bağışlama eğilimleri (genel, kendini, başkalarını ve durumu) cinsiyet açısından anlamlı farklılık göstermemiştir. Alan yazın incelendiğinde bu bulguyu destekleyen araştırmalar (McCullough vd., 1998; Taysi, 2007) bulunmak ile birlikte farklı sonuçlar ortaya koyan çalışmalar da (Hanson, 1996; Miller, Worthington ve McDaniel, 2008) mevcuttur. Aslan vd. (2016) tarafından yapılan bir araştırmada kadınların erkeklere göre hem genel anlamda hem de kendilerini ve başkalarını bağışlamada anlamlı bir şekilde daha bağışlayıcı tutumlar sergiledikleri görülmüştür. Önal (2014) ise üniversite öğrencileri ile yaptığ bağışlama düzeylerinin cinsiyete göre anlamlı farklılık göstermediğini ortaya koymuştur. Bir başka çalışmada da benzer bulgular elde edilmiş, üniversite öğrencilerinin bağışlama eğiliminin cinsiyete göre farklılaşmadığ1 tespit edilmiştir (Kaya, 2015). Görüldüğü gibi bağışlama eğiliminin cinsiyete göre farklılaşıp farklılaşmadığına ilişkin kesin yargılara ulaşmak mümkün değildir. Bu çalışmada da cinsiyet açısından bir farklılığın olmadığ1 görülmektedir. Genel olarak çoğu toplumlarda olduğu gibi Türk toplumunda da bağışlama herkes için bir erdem olarak kabul edilir (Affetmek büyüklüktür gibi) ve cinsiyet fark etmeksizin bağışlayıcı olmak beklenen ve övülen bir özellik olarak görülür. Bu noktadan hare- 
ketle kadın ve erkeklerin aynı düzeyde bağışlayıcı olması beklenir. Bu çalışmada da cinsiyetler arasında önemli bir farklılık ortaya çıkmamıştır.

Araştırmanın önemli bir bulgusu, anne ve babasını demokratik olarak algilayan üniversite öğrencilerinin kendini ve durumu bağışlama eğilimlerinin daha yüksek olması ve aralarında pozitif yönde anlamlı ilişki bulunmasıdır. Demokratik tutum, ebeveynlerin çocuklarına koşulsuz sevgi ve saygı ile yaklaştıkları onlara güven veren ve tutarlı bir ortam sunan tutum olarak tanımlanmaktadır ve çalışmalarda demokratik tutum ile yetişmiş çocukların benlik saygılarının yüksek ve kendilik algılarını daha olumlu olduğu görülmektedir (Erbil, Divan ve Önder, 2006; Sezer ve Oğuz, 2010). Ebeveynleri tarafından olduğu gibi kabul edilen, destek gören, değer verilen bir ortamda yetişen bireyin kendisine yönelik algılarının da olumlu olacağı (Yavuzer, 2000), yaşadığı durum ile ilgili olumsuz duygularından vazgeçerek kendisini hatalarıyla kabul edebilecek bir birey olarak yetişebileceği düşünülmektedir. Anne babasından koşulsuz kabul ve ilgiyi görmüş olan bireyler kendi hatalarını da aynı ölçüde hoş görebilirler, yaşadığı olumsuz duruma karşı bağışlayıcı bir tutum sergileyebilirler. Demokratik tutumla yetişmiş bireylerin kazanmış olduğu özellikleri ile bağışlama eğilimi yüksek kişilerin özellikleri de çok benzerdir. Bağışlayıcılığı yüksek kişiler, psikolojik ve manevi olgunluk kazanmış, yaşam becerileri gelişmiş (Hope, 1987; McCullough ve Worthington, 1994), ilişkilerinde doyum sağlamış (McCullough vd., 1998), kendini olduğu gibi kabul etmiş (Aschleman, 1996), benlik saygısı yüksek (Cardi, 1969; Gündüz, 2014) ve fiziksel sağlı̆̆ yerinde (Huang ve Enright, 2000) olan kişilerdir. Dolayısıyla anne babasını demokratik olarak algılayan üniversite öğrencilerinin kendini ve durumu bağışlama eğilimlerinin yüksek olması beklenen bir bulgu olduğu söylenebilir.

Araştırmanın son bulgusu ise algılanan ana-baba tutumu koruyucuistekçi ve otoriter tutum olan üniversite öğrencilerinin genel, kendini ve durumu bağışlama eğilimlerinin düşük bulunması ve aralarında negatif yönde anlamlı bir ilişki saptanmasıdır. Otoriter ve koruyucu-istekçi tutum da ebeveynlerin çocuklarının kendilerine yeter hale gelmelerinin engelledikleri tutumlardır. Otoriter tutumda ana-baba çocuklarının kendilerine yetebilme güçlerini otorite ile baskıladığı, koruyucu-istekçi tutumda ise ana-baba her şeyi çocuğun yerine yaparak onun kendine yeter hale gelmesini baskıladığı düşünülmektedir. Sonuçta ikisinde de çocu- 
ğun kendisine yönelik algılarının olumsuz etkilenmesi beklenir. Yapılan çalışmalar incelendiğinde otoriter tutum ile yetişmiş bireylerin kendini suçlama ve saldırganlık düzeylerinin yüksek (Öztürk, 1990) olduğu ve öz yetkinlik ve öz farkındalık düzeylerinin düşük bulunduğu (Onat, 2010), koruyucu-istekçi tutum ile yetişmiş bireylerin ise kendilerini daha olumsuz değerlendirdikleri görülmektedir (Sezer ve Oğuz, 2010). Ayrıca otoriter ve koruyucu-istekçi tutum ile yetişmiş bireylerin özellikleri ile bağışlama eğilimi düşük bireylerin özellikleri de çok benzerdir. Bağışlama eğilimi düşük bireylerin ruminasyon eğilimleri, saldırganlık düzeyleri, öfke, düşmanlık, intikam duygularının yüksek olduğu (Berry vd., 2005), daha stresli bir yaşam sürdürdükleri, bunun da fiziksel sağlıklarını olumsuz biçimde etkilediği (Witvliet, Ludwig ve VanderLaan, 2001) daha fazla kaygı ve depresyon yaşadıkları (Lee, 2011) söylenebilir. Dolayısıyla otoriter ve koruyucu- istekçi tutum ile yetişmiş bireylerin genel bağışlama, kendini bağışlama ve durumu bağışlama eğilimlerinin düşük bulunması beklenen bir bulgudur.

$\mathrm{Bu}$ sonuçlar; çocuklarının gelişim ve kişilik özellikleri ile isteklerini dikkate almayan otoriter ana-babalar ile yetişen çocukların bağışlama düzeylerinin çocuklarına koşulsuz sevgi ve saygı gösteren, onlara güven veren ortamlar sunan, sorumluluk almasina firsat taniyan demokratik ana-babalar ile büyüyen çocuklardan daha az bağışlayıcı olduğunu göstermektedir. Gelişim ve kişilik özellikleri dikkate alınmayarak büyüyen çocukların ilerleyen zaman dilimlerinde kendini ve durumu bağışlama konusunda da yetersizlik yaşadıkları düşünülmektedir. Benzer şekilde ebeveynleri tarafından aşırı derecede korunan, denetlenen ve müdahale edilen çocuklar da demokratik tutum sergileyen ebeveynler ile büyüyen akranlarından daha az bağışlayıcı ve daha az kendini ve diğerlerini bağışlama eğilimi gösterdikleri düşünülmektedir. Tüm bu bulgulardan hareketle demokratik ebeveyn tutumuna sahip ebeveynlerin çocuklarının kendini ve durumu bağışlama eğiliminin yüksek olduğu, diğer taraftar otoriter ve koruyucu-istekçi ebeveyn tutumlarına sahip ebeveynlerin çocuklarının hem genel bağışlama eğilimi hem de kendini ve başkasını bağışlama eğilimlerinin düşük olduğu sonucuna varılabilir.

Araştırma sonucunda bağışlama ile ilişkisi tespit edilen ana-baba tutumlarının çocuğun veya gencin kişilik yapılanması üzerinde tesiri olduğu bir kez daha saptanmıştır. Anne baba tarafından çocuğun koşulsuz 
kabul edilmesi ve koşulsuz sevgi verilmesi, tutarlı ortamlar sunulması yani tutumunun demokratikleşmesi arttıkça çocuğun kendini ve durumu bağışlama düzeyi artacağı düşünülmektedir. Aksi ise yani anababanın kendi görüşlerini çocuğa zorla kabul ettirmeye çalıştığı otoriter tutumun ve çocuğa ihtiyacının dışında kontrol ve ilgi gösterilen koruyucu-istekçi tutumun aşırılığı onun bağışlama eğilimini düşürebilir. Bu yüzden anne babalara verilen eğitimlerin önemi ve gerekliliği artan şekilde devam etmektedir.

Üniversite yılları bireylerin yetişkin rollerine hazırlandığı, kişilerarası etkileşimin çeşitlendiği, sorumlulukların arttığı bir dönemdir. Bu karmaşık geçiş döneminde bireyin yaşayabileceği çatışmalar ve kişilerarası sorunlar da artış göstermektedir (Önal, 2014). Öğrenciler mesleki, ekonomik ve gelecek kaygısı gibi birçok problemle daha uğraşmaktadır. Genç; duygusal ilişkilerinin, mesleğinin ve geleceğinin kararını verirken hatalı davranma ihtimali fazlaca yüksek görülmektedir. Dolayısıyla bireyin hataya bakış açısı onun kendini, diğerlerini bağışlama düzeyi ve adapte olma sürecini etkileyecektir (Eraslan ve Arıcıŏ̆lu, 2014). Bağışlamanın öğrenilebilen ve her gelişim döneminde kazanılmasının (Taysi,2007) muhtemel bir beceri olduğu düşünülürse üniversite öğrencilerinin algıladıkları ana-baba tutumları ile bağışlama düzeyleri arasındaki ilişkinin ortaya çıkması gençlere yönelik yapılacak müdahale edici, destekleyici çalışmalar için yol gösterici ve işlevsel olacağı düşünülmektedir.

Bu çalışma, İnönü üniversitesi öğrencileri ile gerçekleştirildiğinden araştırma sonuçlarını Türkiye'ye genellemek mümkün değildir. Ancak alan çalışanlarına zemin oluşturması açısından önem taşıyabilir. Bu araştırma bulguları ışığında öneriler aşağıda sıralanmıştır:

1. Bu çalışmada algılanan ebeveyn tutumu ile bağışlama arasındaki ilişki incelenmiştir, sonraki çalışmalarda bağışlama ile anababanın çocuk yetiştirme stilleri, ödül ve ceza stilleri gibi farklı değişkenlerle ilişkisi incelenebilir.

2. Bu çalışma nicel verilerle gerçekleştirilmiştir. Nitel verilerle bu ilişki daha kapsamlı incelenebilir.

3. Ana-baba tutumları ve bağışlama arasındaki ilişkiye dayanarak anne babalara yönelik önleyici programlar düzenlenip onların demokratik tutum sergileme eğilimleri arttırılarak çocuklarının da bağışlama gibi olumlu eğilimlerin arttırılması sağlanabilir. 
4. Bağışlayıcılığı düşük üniversite öğrencilerinin bağışlama eğilimlerini arttırmak için anne baba etkisini de ele alan eğitim programları düzenlenebilir.

5. Değişkenler arasındaki ilişki farklı örneklem ve yaş gruplarında çalışılarak incelenebilir. 
EXTENDED ABSTRACT

\title{
The Relation Between University Students' Per- ceived Parental Attitudes and Forgiveness Levels
}

\author{
Aslı Tunca - Emine Durmuş \\ İnönü University
}

Family environments have a primary role in the acquisition of the social behaviors, which involves the use of rewards and punishment. The attitudes of parents toward their children shape their perceptions of the environment (Yavuzer, 1990). Forgiveness is one of the important personality traits children learn by identifying with their father or mother (Mccullough and Witvliet, 2002). According to the psychodynamic approach, forgiveness starts in the early years of life and is the result of real or unreal relations with others and internal processes. On the other hand, the object relations theoreticians see forgiveness from the perspective of the relationship established between mother and infant and consider infancy to be important. Whether it is a result of identification or communication with parents, forgiveness is learned in at a very young age. The literature contains studies of the relationships between the concept of forgiveness and the feeling of anger (McCullough, Pargament and Thoresen, 2000; Fincham, Hall and Beach, 2005), anger, disappointment and revenge (Enright et al., 1996), being healthy (Worthington and Scherer, 2004), cognitive distortion (Çivan, 2013), subjective well-being (Yalçın and Malkoç, 2013), and hope, anger and depression (Taysi, Curun and Orcan, 2015). However, there are few studies of the place of forgiveness in family relations. The purpose of this study is to investigate the relationship between university students' perceived parental attitudes, levels of forgiveness and whether forgiveness levels vary by gender. 


\section{Method}

This descriptive study was conducted using the relational screening model. The population of the study was the university students at İnonu University. Its participants were 389 university students, 278 females and 111 males. The data were collected using a personal information form, the Parental Attitude Scale and the Heartland Forgiveness Scale. Since the data of the study were not normally distributed, the SpearmanBrown order differentiation correlation test was used to determine the relationships between the university students' perceived parental attitudes (democratic, authoritarian and protective-demanding) and the students' forgiveness tendencies (general, forgiving themselves, forgiving others and forgiving situations). The Mann Whitney-U test was used to determine whether forgiveness scores varied by gender.

\section{Findings}

This study found that the forgiveness tendencies of the university students did not vary by gender. A relationship was found between the forgiveness tendencies of the participants and parental attitudes. The participants whose perceived parental attitude was democratic had higher tendencies to forgive themselves $(\mathrm{r}=.196, \mathrm{p}<.01)$ and forgive situations $(\mathrm{r}=.122, \mathrm{p}<.05)$, and a statistically significant positive relationship was found between these variables. The participants whose perceived parental attitudes were protective-demanding had lower levels of general forgiveness $(r=-.172, p<.01)$, forgiving themselves $(r=-.174, p<.01)$ and forgiving situations $(\mathrm{r}=-.143, \mathrm{p}<.01)$, and a statistically significant negative relationship was found between them. Finally, the participants whose perceived parental attitude was authoritarian had lower levels of general forgiveness $(\mathrm{r}=-.162, \mathrm{p}<.01)$, forgiving themselves $(\mathrm{r}=-.170, \mathrm{p}<.01)$ and forgiving situations $(\mathrm{r}=-.157, \mathrm{p}<.01)$, and a statistically significant negative relationship was found between them. No statistically significant relationship between parental attitudes and forgiving others was found in this study. Based on these findings, the participants whose perceived parental attitude was democratic had higher tendencies to forgive themselves and situations. However, the participants who perceived 
their parents as protective-demanding or authoritarian had lower levels of general forgiveness, forgiving themselves and situations.

\section{Discussionve Conclusion}

This study found that the forgiveness tendencies of university students did not differ significantly by gender. Although some studies support this finding (McCullough et al.,1998; Taysi, 2007), other studies have found different results (Hanson, 1996; Miller et al., 2008). Therefore, it is not possible to conclude whether forgiveness tendency varies by gender.

This study also found that the university students who perceived their parents' attitudes as democratic had higher levels of forgiving themselves and situations. Other studies have shown that children raised with democratic attitudes have higher self-respect and more positive self-perception (Erbil, Divan and Önder, 2006; Sezer and Oğuz, 2010). Children raised in environments where they are accepted as themselves, supported and valued by their parents will have positive perceptions of themselves (Yavuzer, 2000) and accept themselves along with their faults. Individuals who have been accepted and given attention by their parents without pre-conditions may tolerate their own mistakes and exhibit forgiving attitudes toward negative experiences.

This study found that the university students whose perceived parental attitudes were protective-demanding or authoritarian had a lower tendencies to general forgiveness, forgiving themselves and forgiving situations, and a statistically significant negative relationship was found between them. Authoritarian parents restrict children's autonomy using their authority. Protective-demanding parents try to do everything instead of letting their children do things themselves, and thus restrict their children's efforts to become autonomous. In the end, children's selfperceptions are negatively affected either way. Previous studies have shown that individuals raised with authoritarian attitudes have higher levels of blaming themselves and aggression (Öztürk, 1990), and their self-sufficiency and self-awareness levels are lower (Onat, 2010). Individuals raised with protective-demanding attitudes have negative selfevaluation (Sezer and Oğuz, 2010). Therefore, lower levels of general 
forgiveness, forgiving themselves and situations in individuals raised with authoritarian or protective-demanding attitudes are to be expected.

These results indicate that the forgiveness levels of individuals raised by authoritarian parents who do not consider their children's developmental and personality features are less forgiving than those of individuals raised by democratic parents who love and respect their children, provide them safe environments and give them chances to take responsibility.

\section{Kaynakça/References}

Akhtar, S. (2002). Forgiveness: Origins, dynamics, psychopatology, and technical relevance. Psychoanalytic Quarterly,71(2), 175 - 212. https://doi.org/10.1002/j.2167-4086.2002.tb00010.x

Alpay, A. (2009). Yakın ilişkilerde bağışlama: Bağışlamanın; bağlanma, benlik saygısı, empati ve kıskançlık değişkenleri yönünden incelenmesi (Yayımlanmamış yüksek lisans tezi). Ankara Üniversitesi, Sosyal Bilimler Enstitüsü, Ankara.

Aschleman, K. A. (1996). Forgiveness as a resiliency factor in divorced or permanently separated families(Unpublished master's thesis). University of Wisconsin, Madison.

Aslan, M., Mert, Ş. H. ve Yıldız, M. (2016). Narsist kişilik ile affedicilik arasindaki ilişkinin incelenmesi. 2. Ulusararası Çin'den Adriyatik'e Sosyal Bilimler Kongresi, 147-153. 5-7 Mayıs, 2016, Hatay.

Battle, C. L.,ve Miller, I. W. (2015). Families and forgiveness, In E. L. Worthington (Ed.), Handbook of forgiveness (pp. 227-241). New York: Routledge.

Baumrind, D. (1966). Effects of authoritative control on child behavior. Child Development, 37(4), 887-907. http://dx.doi.org/10.2307/1126611

Baumrind, D. (1968). Authoritarian vs. authoritative parental control. Adolescence, 3(11), 255-272. 
Berry, J. W.,Worthington, E. L., O'Connor, L. E., Parrott, L., ve Wade, N. G. (2005). Forgivingness, vengeful rumination, and affective traits. Journal of personality, 73(1), 183-225. https://doi.org/10.1111/j.1467-6494.2004.00308.x

Bilal, G. (1984). Demokratik ve otoriter olarak algilanan ana-baba tutumlarmm çocuklarm uyum düzeylerine etkisi (Yayımlanmamış doktora tezi). Hacettepe Üniversitesi, Sosyal Bilimler Enstitüsü, Ankara.

Bono, G. ve McCullough, M. E. (2004). Religion, forgiveness, and adjustment in older adulthood, In K. W. Schaie, N. Krause, ve A. Booth (Eds.), Religious influences on health and well-being in the elderly (pp. 163-187). New York: Springer Publishing.

Bugay, A. ve Demir, A. (2010). A Turkish version of heartland forgivenss Scale. Procedia Social and Behavioral Sciences, 5(2010), 1927-1931. https://doi.org/10.1016/j.sbspro.2010.07.390

Cardi, M. K. (1969). Views of the self andinter-connectedness as predictors of forgiveness (Unpuslished doctoral dissertation). University of Kentucky, Lexington.

Conner, K. M. ve Davidson, J. R. (2003). Development of a new resilience scale: The conner-davidson resilience scale (CD-RISC). Depression and Anxiety, 18(2), 76-82. https://doi.org/10.1002/da.10113

Çivan. İ. (2013). Üniversite Öğrencilerinin kişilerarası ilişkilerle ilgili bilişsel çarpıtmaları ve başkalarını bağışlama davranışlarının incelenmesi (Yayımlanmamış yüksek lisans tezi). Gazi Üniversitesi, Eğitim Bilimleri Enstitüsü, Ankara.

Dönmezer, İ. (1999). Ailede iletişim ve etkileşim. İstanbul: Sistem Yayınc1lik.

Eldeleklioğlu, J. (1999). Karar stratejileri ile ana-baba tutumları arasında ilişki. Türk Psikolojik Danışma ve Rehberlik Dergisi, 2(11), 7-13. https://doi.org/10.17066/pdrd.52269

Enright, R. D. (1996). Counseling within the forgiveness triad: On forgiving, receiving, forgiveness and self-forgiveness. Counseling and Values, $\quad 40(2)$, 107-126. https://doi.org/10.1002/j.2161007X.1996.tb00844.x

Enright, R. D.,Gassin, E. A. ve Wu, C. (1992). Forgiveness: A developmental view. Journal of Moral Education, 21(2), 99-114. https://doi.org/10.1080/0305724920210202 
Eraslan, Ç. B. ve Arıcıoğlu, A. (2014). Psikolojik sağlamlığın yordayıcısı olarak affedicilik. E-International Journal of Educational Research, 5(4), 70-82. https://doi.org/10.19160/e-ijer.05325

Erbil, N., Divan, Z. ve Önder, P. (2006). Ergenlerin benlik saygısına ailelerinin tutum ve davranışlarının etkisi. Aile ve Toplum Ĕ̆itim Kültür ve Araştırma Dergisi, 3(10), 7-15.

Erikson, E. H. ( 1963). Childhood and society (2nd ed.). New York: W.W.Norton.

Exline, J. J. ve Baumeister, R. F. (2000). Expressing forgiveness and repentance, In M. E. McCullough, K. I. Pargament, ve C. E. Thoresen, (Eds.), Forgiveness: Theory, research, and practice (pp. 133155). New York: Guilford Publications.

Fincham, F.D.,Hall, J.H., ve Beach, S.R.H. (2005). Till lack of forgiveness do us part, forgiveness in marriage, In E.L. Worthington (Ed.), Handbook of Forgiveness (pp.207- 226). New York: Wiley.

Gazeloğlu, C. (2000). İlkokul dördüncü sinıf öğrencilerinin psiko-sosyal gelişimine ana baba tutumunun etkisinin incelenmesi (Yayımlanmamış yüksek lisans tezi). Hacettepe Üniversitesi, Sağlık Bilimleri Enstitüsü, Ankara.

Gündüz, Ö. (2014). Üniversite öğrencilerinde affetmeyi yordayan değiş̧kenlerin belirlenmesi (Yayımlanmamış yüksek lisans tezi). Ankara Üniversitesi, Eğitim Bilimleri Enstitüsü, Ankara.

Hall, J.H. ve Fincham, F.D. (2005). Self-forgiveness: The stepchild of forgiveness research. Journal of Social and Clinical Psychology, 24(5), 621-637.https://doi.org/10.1521/jscp.2005.24.5.621

Hanson, D. J. (1996). Psychologists' use of forgiveness in psychotherapy (Unpublished doctoral dissertation). Antioch College, Yellow Springs.

Hope, D. (1987). The healing paradox of forgiveness. Psychotherapy, 24(2), 240-244. http://dx.doi.org/10.1037/h0085710

Huang, S. T. T.,ve Enright, R. D. (2000). Forgiveness and anger-related emotions in Taiwan: Implications for therapy. Psychotherapy, 37(1), 171-179.http://dx.doi.org/10.1037/h0087831

Humpyres, T. (1998). Çocuk eğitiminin anahtarı (T. Anapa, Çev.). İstanbul: Epsilon Yayıncllı. 
İkizoğlu, M. (1993). Demokratik ve otoriter ana-baba tutumlarmın, lise son sinıf öğrencilerinin benlik saygısı üzerine etkisi (Yayımlanmamış yüksek lisans tezi). Hacettepe Üniversitesi, Sosyal Bilimler Enstitüsü, Ankara.

Kara, E. (2009). Dini ve psikolojik açıdan bağışlayıcılı̆̆ın terapötik değeri. Uluslararası Sosyal Araştırmalar Dergisi, 2(8), 222-228.

Karasar, N. (2011). Bilimsel Araştırma Yöntemi (22. Bs.). Ankara: Nobel Akademik Yayıncilik.

Karremans, J. C. K., Van Lange, P. A., Ouwerkerk, J. W. ve Kluwer, E. S. (2003). When forgiving enchances psychological well-being: The role of interpersonal commitment. Journal of Personality and Social Psychology, 84(5), 1011-1026. http://dx.doi.org/10.1037/00223514.84.5.1011

Kaya, A.,Bozaslan, H. ve Genç, G. (2012). Üniversite öğrencilerinin annebaba tutumlarının problem çözme becerilerine, sosyal kaygı düzeylerine ve akademik başarılarına etkisi. Dicle Üniversitesi Ziya Gökalp Ĕ̆itim Fakültesi Dergisi, 18(2012) 208-225.

Kaya, F. (2015). Üniversite öğrencilerinin affetme ve mükemmeliyetçilik düzeyleri arasındaki ilişki: Duygusal zekanın aracı rolü (Yayımlanmamış yüksek lisans tezi). Ankara Üniversitesi, Eğitim Bilimleri Enstitüsü, Ankara.

Kehale, D. (2002). Okul öncesi öğretmenliği programı öğrencilerinin algıladıkları anne baba davranışları, kendilik algısı ve empatik beceri düzeyleri ve bunlar arasındaki ilişki (Yayımlanmamış yüksek lisans tezi). Marmara Üniversitesi, Eğitim Bilimleri Enstitüsü, İstanbul.

Kuzgun, Y. (1991). Ana-baba tutumlarının bireyin kendini gerçekleştirme düzeyine etkisi. B. Dikeçligil ve A. Çiğdem (Ed.) içinde, Aile Yazıları 3 Birey, Kişilik ve Toplum (ss.65-78). Başbakanlık Aile Araştırma Kurumu: Ankara.

Kuzgun, Y. ve Eldeleklioğlu, J. (2005). Ana baba tutumları ölçeği (ergenler ve yetişkinler için). Y. Kuzgun, ve F. Bacanlı (Ed.) içinde, Rehberlik ve psikolojik danışmada kullanılan ölçme araçları ve programları dizisi: 1, PDR'de kullanılan ölçekler (ss. 53-70). Nobel Yayınları: Ankara. 
Lee, K. H. (2011). The role of spiritual experience, forgiveness, and religious support on the general well-being of older adults. Journal of Religion, Spirituality ve Aging, 23(3), 206 223. https://doi.org/10.1080/15528030.2011.533398

Mauger, P. A., Perry, J. E., Freeman, T., ve Grove, D. C. (1992). The measurement of forgiveness: Preliminary research. Journal of Psychology and Christianity, 11(2), 170-180.

McCullough, M. E. ve Witvliet, C. O. (2002). The psychology of forgiveness. In C. R. Sydner ve S. J. Lopez (Eds.), Handbook of Positive Psychology (pp. 446-458). New York, Oxford University Press.

McCullough, M. E. ve Worthington, E. L. (1994). Encouraging clients to forgive people who have hurt them: Review, critique, and research prospectus. Journal of Psychology and Theology, 22(1), 3-20. https://doi.org/10.1177/009164719402200101

McCullough, M. E.,Rachal, K. C., Sandage, S. J., Worthington, E. L., Brown, S. W., ve Hight, T. L. (1998). Interpersonal forgiving in close relationship II: Theoretical elaboration and measurement. Journal of Personality and Social Psychology, 75(6), 1586-1603.

McCullough, M.E., Pargament, K. I., ve Thoresen, C. E. (2000). The psychology of forgiveness: History, conceptual issues, and overwiew. In M.E. McCullough, K.I Pargament, ve C.E. Thoresen (Eds.), Forgiveness: Theory, research, and practice (pp.1-14). New York: Guildford.

McWhirter, J. ve Acar, V.N. (1991). Çocukla İletişim: Öğretme, Destekleme ve Çocuk Yetiştirme Sanatı. Ankara: MEB yayınları.

Miller, A. J.,Worthington, E. L., ve McDaniel, M. A. (2008). Gender and forgiveness: A meta-analytic review and research agenda. Journal of Social and Clinical Psychology, 27(8), 843-876. https://doi.org/10.1521/jscp.2008.27.8.843

Mullet, E.,Girard, M., ve Bakhshi, P. (2004). Conceptualizations of forgiveness. European Psychologist, 9(2), 78-86. http://dx.doi.org/10.1027/1016-9040.9.2.78

Onat, G. (2010). Demokratik ve otoriter olarak algilanan ana-baba tutumlarmin lise birinci sımı öğrencilerinin yılmazlı düzeyine etkilerinin araştırılması (Yayınlanmamış yüksek lisans tezi). Maltepe Üniversitesi, Sosyal Bilimler Enstitüsü, İstanbul. 
Önal, A. A. (2014). Bilişsel çarpıtmalar, empati ve ruminasyon düzeyinin affetmeyi yordama gücünün incelenmesi (Yayımlanmamış doktora tezi). Ankara Üniversitesi, Eğitim Bilimleri Enstitüsü, Ankara.

Öner, N. (2012). Türkiye'de kullanilan psikolojik testlerden örnekler (7. Bs.). İstanbul: Boğaziçi Üniversitesi Yayınevi.

Öztürk, İ. (1990). Ana-baba tutumlarının üniversite öğrencilerinin bağımsızlık, duyguları anlama, yakınlık, başatlık, kendini suçlama ve saldırganlık düzeylerine etkisi (Yayımlanmamış yüksek lisans tezi). Hacettepe Üniversitesi, Sosyal Bilimler Enstitüsü, Ankara.

Piaget, J. (1932). The moral judgment of the child. London: The Free Pres.

Rohner, R.P. (2005). Glossary of significant concepts in parental acceptance-rejection theory. 28 Nisan 2014 tarihinde https://www.researchgate.net/publication/255709642_Glossary_of_significant_concepts_in_Parental_Acceptance-Rejection_Theory_PARTheory adresinden alınmıştır.

Rye, M. S.,ve Pargament, K. I. (2002). Forgiveness and romantic relationships incollege: Can it heal the wounded heart?.Journal of Clinical Psychology, 58, 419-441.https://doi.org/10.1002/jclp.1153

Sarıçam, H. ve Biçer, B. (2015). Affedicilik üzerinde ahlaki değer ve özanlayışın açıklayıcı rolü. Gazi Üniversitesi Gazi Ĕ̆itim Fakültesi Dergisi, 35(1), 109-122. https://doi.org//10.1080/15298868.2011 .649546

Schultz, P. D., ve Schultz, S. E. (2002). Modern Psikoloji Tarihi (Y. Aslay, Çev.). İstanbul: Kaknüs Yayınları.

Seligman, M. E. (2002). Positive psychology, positive prevention, and positive therapy, In C. Snyderve S. Lopez (Eds.), Handbook of positive psychology (pp. 3-12). New York: Oxford.

Sezer, Ö. ve Oğuz, V. (2010). Üniversite öğrencilerinde kendilerini değerlendirmelerinin anne baba tutumları ve bazı sosyo-demografik değişkenler açısından incelenmesi. Kastamonu Ĕ̆itim Dergisi, 18(3): 743-758.

Taysi, E. (2007). İkili ilişkilerde bağışlama: İlişki kalitesi ve yüklemelerin rolü (Yayımlanmamış doktora tezi). Ankara Üniversitesi, Sosyal Bilimler Enstitüsü, Ankara. 
Taysi, E.,Curun, F., ve Orcan, F. (2015) Hope, anger and depressiyon as meditors for forgiveness and social behaivor in Turkish children. The journal of psychology,149(3-4), 378-93. https://doi.org/10.1080/00223980.2014 .881313

Thompson, L.Y.,Snyder, C. R., Hoffman, L., Micheal, S. T., Rasmussen, H. N., Billings, L. S., ve Heinze, L.,...Roberts, D.E. (2005). Dispositional forgiveness of self, others, and situations. Journal of Personality, 73(2), 313-359. https://doi.org/10.1111/j.14676494.2005.00311.x

Toussaint, L. L.,Worthington, E. L., ve Williams, D. R. (2015). Forgiveness and health: Scientific evidence and theories relating forgiveness to better health. Dordrecht: Springer.

Tuck, I., ve Anderson, L. (2014). Forgiveness, flourishing, and resilience: The influences of expressions of spirituality on mental health recovery. Issues in Mental Health Nursing, 35(4), 277282.https://doi.org/10.3109/01612840.2014.885623

Tuzgöl, M. (1998). Ana-baba tutumları farklı lise öğrencilerinin saldırganlık düzeylerinin çeşitli değiş̧kenler açısından incelenmesi (Yayımlanmamış yüksek lisans tezi). Hacettepe Üniversitesi, Sosyal Bilimler Enstitüsü, Ankara.

Walker, D. F.,ve Gorsuch, R. L. (2002). Forgiveness within the big five personality model. Personality and Individual Differences, 32(7), 1127-1137. http://dx.doi.org/10.1016/S0191-8869(00)00185-9

Witvliet, C., Ludwig, T. E., ve VanderLaan, K. L. (2001). Granting forgiveness or harboring grudges: Implications for emotion, physiology, and health. Psychological Science, 12(2), 117-123. https://doi.org/10.1111/1467-9280.00320

Worthington, E. L.,ve Scherer, M. (2004). Forgiveness is an emotionfocused coping strategy that can reduce health risks and promote health resilience: Theory, review, and hypotheses. Psychology ve Health, 19(3), 385-405.

Yalçın, İ., ve Malkoç, A. (2015). The relationship between meaning in life and subjective well-being: Forgiveness and hope as mediators. Journal of Happiness Studies, 16(4), 915-929. https://doi.org/10.1007/s10902-014-9540-5

Yavuzer, H. (1990). Ana baba okulu. İstanbul: Remzi Kitabevi. 
Yavuzer, H. (2000). Ana-baba ve çocuk (13. Bs.). İstanbul: Remzi Kitabevi. Yıldız, M. (2004). Annesi çalışan ve çalışmayan çocukların anne baba tutumlarinı algilamalarmm ve benlik imajlarmin incelenmesi (Yayımlanmamış yüksek lisans tezi). Ankara Üniversitesi, Fen Bilimleri Enstitüsü, Ankara.

\section{Kaynakça Bilgisi / Citation Information}

Tunca, A. ve Durmuş, E. (2018). Üniversite öğrencilerinin algıladıkları anne baba tutumu ile bağışlama düzeylerinin ilişkisi. OPUSUluslararası Toplum Araştırmaları Dergisi, 9(16), 524-550. DOI: 10.26466/opus. 470406 